Nasrulloh, A., Deviana, P., Yuniana, R., \& Pratama, K.W. (2021). The Effect of Squat Training and Leg Length in Increasing the Leg Power of Volleyball Extracurricular Participants. Teoriâ ta Metodika Fizičnogo Vihovannâ, 21(3), 244-252.

https://doi.org/10.17309/tmfv.2021.3.08

ISSN 1993-7989 (print). ISSN 1993-7997 (online). ISSN-L 1993-7989

ORIGINAL SCIENTIFIC ARTICLE

\title{
THE EFFECT OF SQUAT TRAINING AND LEG LENGTH IN INCREASING THE LEG POWER OF VOLLEYBALL EXTRACURRICULAR PARTICIPANTS
}

\author{
Ahmad Nasrulloh ${ }^{1 \mathrm{BCDE}}$, Putri Deviana ${ }^{1 \mathrm{BDE}}$, Rina Yuniana ${ }^{1 \mathrm{BCE}}$, Kukuh Wahyudin Pratama $^{2 \mathrm{CDE}}$ \\ ${ }^{1}$ Yogyakarta State University \\ ${ }^{2}$ Institute of Advanced Science, Engineering, and Education \\ Authors' Contribution: A - Study design; B - Data collection; C - Statistical analysis; D - Manuscript Preparation; E - Funds Collection
}

Corresponding Author: Ahmad Nasrulloh, E-mail: ahmadnasrulloh@uny.ac.id

Accepted for Publication: August 25, 2021

Published: September 25, 2021

DOI: $10.17309 /$ tmfv.2021.3.08

\begin{abstract}
The study purpose. This study aims to see: (1) The difference in the effect of barbell squat and resistance band squat exercises on the increase in leg power. (2) The difference in influence between players who have high leg height and low leg length on the increase in leg power. (3) The interaction of barbell squat and resistance band squat exercises with leg length (high and low) to increase the power of volleyball extracurricular participants.

Materials and Methods. This is an experimental research using a $2 \times 2$ factorial design. The population in this study were 38 volleyball extracurricular participants at SMA Negeri 1 Sedayu. The sample in this study may be 20 people. Instruments used for measuring: a tape measure for the length of the legs and a vertical jump for the power of the legs. The data analysis technique used was two-way ANOVA.

Results. The result showed that (1) There was a significant effect between barbell squat and resistance band squat exercises on the increase in the power of volleyball extracurricular participants, with an F value of 65.789 and a significance value of $\mathrm{p}=0.000(<0.05)$. The squat group has a higher resistance band (good) compared to the barbell squat group with an average difference of 2.5. (2) There was a significant difference in the effect of players who have high leg height and low leg length on the increase in leg power of volleyball extracurricular participants, it is proven that the $\mathrm{F}$ value is 38.000 and the significance value is $\mathrm{p}=0.000(<0.05)$. Players who have high leg length are higher (good) compared to players who have low leg length with an average difference of 1.90. (3) There was a significant interaction between barbell squat and resistance band squat and leg length (high and low) on the leg power increase of volleyball extracurricular members, with an F value of 88.256 and a significance of $\mathrm{p}=0.000(<0.05)$.

Conclusions. There was a significant difference in the effect of barbell squats and resistance band squats on increasing leg power, there was a significant difference in the effect between players who have high leg length and low leg length on the increase in leg power, and There is a significant interaction between barbell squats and squat resistance bands and leg length (high and low) on the increase in leg power of volleyball extracurricular participants. Keywords: barbell squats, resistance band squats, leg power, leg length.
\end{abstract}

\section{Introduction}

The physiological character of volleyball is determined by the specific offensive and defensive performance of the players such as jumps to spike, leaps in different directions or sprints to the ball at distances up to $10 \mathrm{~m}$ (Sarabia et al., 2017). Kumar, Goswami, and Kumar (2016) added that "While spiking \& blocking a player has to jump vertically in order to make contact with the ball from maximum height". Leg muscle power is the ability of a person to exert maximum strength and speed to overcome resistance or load (Zemková

(C) Nasrulloh, A., Deviana, P., Yuniana, R., Pratama, K.W., 2021. et al., 2017). Another opinion according to Bompa and Haff (2019) "Power is the result of two abilities; maximum speed and strength in the shortest possible time". Based on both opinions, high jumping can be achieved by doing exercises related to power or explosive power.

It was explained that one of the components in volleyball is power. Suresh and Perinbaraj (2016) states that "explosive power (muscular power) is a person's ability to use the maximum strength that is deployed in the shortest possible time". Power is a combination of strength and speed or the maximum exertion of muscle force with maximum speed, strong and fast abilities are needed, especially for actions 
that require maximum power capabilities such as smashing movements (Wirth et al., 2016).

Based on the results of observations on volleyball extracurricular participants at SMA Negeri 1 Sedayu, it shows that the exercises applied by the coaches are less varied. The coach just emphasizes technical practice and continues with the game. As stated by Bompa and Haff (2019) that "suggested that a lack of training variation can result in what is termed monotonous program overtraining". Another gap found is the low jump of players when doing smash or blocking. The latest data when performing the leg power test with the vertical jump test showed that the average jump height of the players was $30.8 \mathrm{~cm}$. These results when converted into the table of Physical Fitness Tests for Indonesians aged 16-19 years are in the poor category. Volleyball players, if they have good power legs, it will be more effective and efficient in performing techniques, especially smash and block (Challoumas \& Artemiou 2018).

Therefore, it is necessary to apply the right training method to increase power. Many studies use the plyometric training method to increase power, but weight training can also be used to increase athlete's power. The results of Brown et al. (Aghajani et al. 2014) showed "examined the effect of two plyometric training with weightlifting programs on aesthetic jumping ability among men at university. Squats are a very simple movement. This movement can start from a standing position and then squat and return to the standing position as before. Bryanton et al. (2018) revealed that to perform squat movements must have the right basic strength, for athletes or players who have basic strength and poor flexibility, it is recommended to perform squat movements without using weights first.

Csapo (2016) explains weight training is a good enough training method to build muscle than other methods, building muscle strength is very important for non-athletes and athletes from various sports, training hard to strengthen muscles means also keeping from injury while doing sports. In order to avoid injury when doing weight training, there needs to be a systematic training program that can show the amount of weight that must be done at the time of training. Several forms of exercise to develop power, including weight training/barbells (12-16 RM) or strength training (8-12 RM) and continued with speed training (Wallace, Winchester, \& McGuigan, 2006).

In the field there are still many trainers who do not know the form of power exercises using rubber resistance bands. Radu, Făgăraş, and Graur (2015) argue that the combination of resistance band exercises is very effective in improving the height of the jump and the strength of the legs, increasing speed, agility. In addition, exercises using resistence bands can also increase joint strength and can be used for aerobic exercises. Based on the background that has been stated above, the researchers are interested in conducting a study entitled "The Effect of Barbell Squat Exercises and Squat Resistance Bands and Leg Length on Increasing Leg Power of Volleyball Extracurricular Participants at SMA Negeri 1 Sedayu".

This study aims to see: (1) The difference in the effect of barbell squat and resistance band squat exercises on the increase in leg power. (2) The difference in influence between players who have high leg height and low leg length on the increase in leg power. (3) The interaction of barbell squat and resistance band squat exercises with leg length (high and low) to increase the power of volleyball extracurricular participants.

\section{Materials and Methods}

\section{Study Participants}

This type of research is an experiment using a factorial design of $2 \times 2$. Sugiyono (2015) states that factorial is an action on one or more variables that are manipulated simultaneously in order to study the effect of each variable on the dependent variable or the effect caused by the interaction between several variables. This experimental study used two groups that received different treatments, namely barbell squats and resistance band squats. The population in this study was volleyball extracurricular participants at SMA Negeri 1 Sedayu which amounted to 38 people. Siyoto \& Sodik (2015) state that the sample is part of the number and characteristics possessed by the population, or a small part of the population members taken according to certain procedures so that they can represent the population. Total population 38 players in the leg length test. This test is used to determine the leg length of the player. After the leg length data is collected, an analysis is then performed to identify the group of players with high and low legs using the overall test score of the length of the legs owned by the player by ranking.

\section{Study Organization}

Based on the ranking, 27\% of the upper group and 27\% of the lower group of test results were determined (Dearing, 2019). Thus the grouping of samples taken from players who have high legs as much as $27 \%$ and players who have low legs as much as $27 \%$ of the data that has been ranked. Based on this, 10 people have high legs and 10 people have low legs. Then from each of these data, they were divided into two groups by ordinal pairing and it was found that 5 people with tall legs were treated with barbell squats and resistance band squats. The same treatment is also performed for groups of players who have low legs. The division of groups in this way will be more objective for all research subjects. This is based on equal opportunity for all objects to be included in each group. After being divided into four groups, each group of high and low legs performs pretest using vertical jump test instrument before treatment.

\section{Statistical Analysis}

The variables in this study consisted of two independent manipulative variables, namely barbell squats and resistance band squats, while the attributive independent variable was leg length. Then the dependent variable is leg power.

The barbell squat exercise is an exercise method with the form of movement starting from a standing position then squatting and returning to a standing position as before by being given a weight in the form of a barbell with a predetermined weight.

Squat resistance band exercise, which is an exercise in the form of movement starting from a standing position then squatting and returning to a standing position as before by being given a resistance band with the same size of 
Table 1. Pretest and Posttest Data on Leg Power

\begin{tabular}{|c|c|c|c|c|c|c|}
\hline \multirow{3}{*}{ No } & \multicolumn{6}{|c|}{ High Leg Group } \\
\hline & \multicolumn{3}{|c|}{ Squat Barbell (A1B1) } & \multicolumn{3}{|c|}{ Squat Resistance Band (A2B1) } \\
\hline & Pretest & Posttest & Difference & Pretest & Posttest & Difference \\
\hline 1 & 32 & 33 & 1 & 32 & 38 & 6 \\
\hline 2 & 31 & 31 & 0 & 32 & 38 & 6 \\
\hline 3 & 31 & 32 & 1 & 30 & 35 & 5 \\
\hline 4 & 30 & 31 & 1 & 30 & 38 & 8 \\
\hline 5 & 29 & 30 & 1 & 29 & 35 & 6 \\
\hline \multirow[t]{3}{*}{ Mean } & 30.6 & 31.4 & 0.8 & 30.6 & 36.8 & 6.2 \\
\hline & Percentage & & $2.1 \%$ & & & $20.26 \%$ \\
\hline & \multicolumn{6}{|c|}{ Low Leg Group } \\
\hline \multirow[t]{2}{*}{ No } & \multicolumn{3}{|c|}{ Squat Barbell (A1B2) } & \multicolumn{3}{|c|}{ Squat Resistance Band (A2B2) } \\
\hline & Pretest & Posttest & Difference & Pretest & Posttest & Difference \\
\hline 1 & 26 & 27 & 1 & 26 & 27 & 1 \\
\hline 2 & 25 & 27 & 2 & 25 & 26 & 1 \\
\hline 3 & 23 & 25 & 2 & 22 & 24 & 2 \\
\hline 4 & 20 & 22 & 2 & 20 & 22 & 2 \\
\hline 5 & 18 & 20 & 2 & 17 & 18 & 1 \\
\hline \multirow[t]{2}{*}{ Mean } & 22.4 & 24.2 & 1.8 & 22 & 23.4 & 1.4 \\
\hline & Percentage & & $8.04 \%$ & \multicolumn{2}{|c|}{ Percentage } & $6.36 \%$ \\
\hline
\end{tabular}

Table 2. Descriptive Statistics of Pretest and Posttest of Leg Power

\begin{tabular}{lcccc}
\hline \multicolumn{1}{c}{ Group } & Minimum & Maximum & Mean & $\begin{array}{c}\text { Std. } \\
\text { Deviation }\end{array}$ \\
\hline Pretest A1B1 & 29.00 & 32.00 & 30.60 & 1.14 \\
Posttest A1B1 & 30.00 & 33.00 & 31.40 & 1.14 \\
Pretest A2B1 & 29.00 & 32.00 & 30.60 & 1.34 \\
Posttest A2B1 & 35.00 & 38.00 & 36.80 & 1.64 \\
Pretest A1B2 & 18.00 & 26.00 & 22.40 & 3.36 \\
Posttest A1B2 & 20.00 & 27.00 & 24.20 & 3.11 \\
Pretest A2B2 & 17.00 & 26.00 & 22.00 & 3.67 \\
Posttest A2B2 & 18.00 & 27.00 & 23.40 & 3.58 \\
\hline
\end{tabular}

elasticity. The use of rubber resistance bands for treatment is always weighed at each training session, so each session before the treatment, the elasticity of the resistance band has been measured. For treatment model must be different from the length of elasticity rubber resistance band, because there is a heavier load to use it is the experimental group (testi).

Leg length is the presence of a leg measured from the groin to the sole of the foot and measured using a meter in centimeters.

Leg muscle power is the ability of the leg muscles to exert maximum strength in a very fast time and measured using vertical jump test with centimeters.

\section{Results}

The data from this study are in the form of pretest and posttest leg power data. The research process will take place in three stages. The first stage is to do a pretest to get initial data on the assessment of leg length and leg power on June 29,2020 . The second phase of this research activity is to conduct treatment, this research lasts for 2 months, from July 1, 2020 to August 8, 2020. The implementation of the treatment will last for 6 weeks with a frequency of 3 times a week. The data of pretest and posttest power legs are presented in Table 1 as follows.

Descriptive statistics of pretest and posttest leg power are presented in Table 2 as follows.

When displayed in the form of a diagram, the leg power data is presented in Figure 1 as follows:

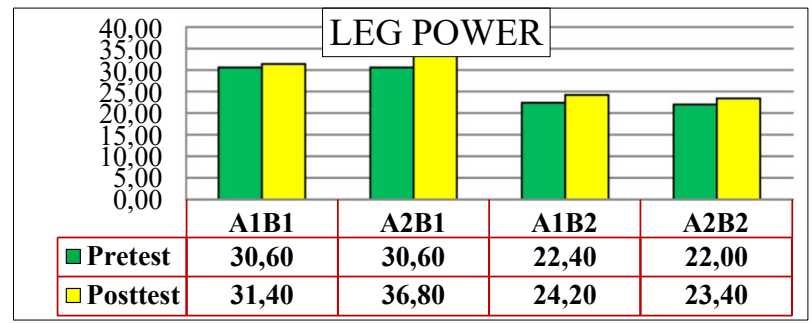

Figure 1. Pretest and Posttest Legs Power Chart Diagram Information:

A1B1: Athletes trained using the barbell squat exercise method with high leg length

$\mathrm{A} 2 \mathrm{~B} 1$ : Athletes trained using the squat resistance band exercise method with high leg length

A1B2. Athletes trained using the barbell squat exercise method with low leg length

A2B2. Athletes trained using the squat resistance band exercise method with low leg length

Based on the graph above, it shows that the leg power of the A1B1 group has an average prestest of $30.60 \mathrm{~cm}$ and has increased at the posttest of $31.40 \mathrm{~cm}$, the $\mathrm{A} 2 \mathrm{~B} 1$ group has an average prestest of $30.60 \mathrm{~cm}$ and has increased at the posttest of $36.80 \mathrm{~cm}$, the A1B2 group has an average prestest of $22.40 \mathrm{~cm}$ and has increased at the posttest of $24.20 \mathrm{~cm}$, the A2B2 group has an average prestest of $22.00 \mathrm{~cm}$ and has increased at the posttest of $23.40 \mathrm{~cm}$. 


\section{Prerequisite Test Results}

\section{Normality Test}

Test normality data in this study used Shapiro-Wilk method. The results of the data normality test carried out in each group were analyzed using the SPSS version 20.0 software program for windows with a significance level of $5 \%$ or 0.05 . The summary is presented in Table 3 as follows.

Table 3. Summary of Normality Test Results

\begin{tabular}{lccc}
\hline \multicolumn{1}{c}{ Group } & p & Significance & Description \\
\hline Pretest A1B1 & 0.814 & & Normal \\
Posttest A1B1 & 0.814 & & Normal \\
Pretest A2B1 & 0.201 & & Normal \\
Posttest A2B1 & 0.206 & \multirow{2}{*}{0.05} & Normal \\
Pretest A1B2 & 0.677 & & Normal \\
Posttest A1B2 & 0.332 & & Normal \\
Pretest A2B2 & 0.787 & & Normal \\
Posttest A2B2 & 0.685 & & Normal \\
\hline
\end{tabular}

Based on the statistical analysis of the normality test that has been carried out using the Shapiro-Wilk test in Table 3 above, it shows that all the pretest and posttest data on leg power were obtained from the results of the normality test of the data, the significance value of $p>0.05$, which means the data is normally distributed. The complete calculation results are presented in appendix 6 on page 166.

Homogeneity Test

Homogeneity test is conducted to test the equation of some samples i.e. homogeneous or not. Homogeneity test is intended to test the similarity of variants between pretest and posttest. The homogeneity test in this study was the Levene Test. Homogeneity test results are presented in Table 4 as follows.

Table 4. Summary of Homogeneity Test Results

\begin{tabular}{cccc}
\hline F & df1 & df2 & Sig. \\
\hline 1.009 & 3 & 16 & 0.414 \\
\hline
\end{tabular}

Based on statistical analysis of homogeneity test that has been conducted using Levene Test Wilk in Table 4 above the calculation results obtained a significance value of 0.414 0.05 . This means that the data group has a homogeneous variant. Thus the population has the same variance or is homogeneous.

\section{Hypothesis Test Results}

The testing of the research hypothesis was conducted based on the results of data analysis and interpretation of two-way ANOVA analysis (two-way ANOVA). The order of hypothesis test results is adjusted to the hypothesis formulated in chapter II, as follows.

The Hypothesis of the Difference in the Effect of Barbell Squats and Resistance Band Squats on Increasing Leg Power

The first hypothesis states "There is a significant difference in influence between barbell squat exercises and squat resistance bands against the increased power of volleyball extracurricular participants at SMA Negeri 1 Sedayu". Based on the results of the analysis obtained data in Table 5 as follows.
Table 5. ANOVA Test Results between Barbell Squat Exercises and Squat Resistance Bands on Increasing Leg Power

\begin{tabular}{cccccc}
\hline Source & $\begin{array}{c}\text { Type III Sum of } \\
\text { Squares }\end{array}$ & df & $\begin{array}{c}\text { Mean } \\
\text { Square }\end{array}$ & F & Sig \\
\hline Group_Practice & 31.250 & 1 & 31.250 & 65.789 & 0.000 \\
\hline
\end{tabular}

From the results of the ANOVA test in Table 5 above, it can be seen that the significance value of $p$ is 0.000 and the $\mathrm{F}$ value is 65.789 . Because the significance value of $\mathrm{p}$ is $0.000<0.05$, it means that $\mathrm{H} 0$ is rejected. Thus there are significant differences in influence. Based on the results of the analysis, the squat resistance band exercise group was 3.80 higher (good) compared to the barbell squat exercise group of 1.30 with a posttest average difference of 2.5 . This means that the research hypothesis which states that "There is a significant difference in the effect of barbell squats and resistance band squats on increasing leg power in volleyball extracurricular participants at SMA Negeri 1 Sedayu", has been proven.

The Hypothesis of the Difference in the Effect Between Players who have High Leg Length and Low Leg Length on Increasing Leg Power

The second hypothesis states "There is a significant difference in the effect between players who have high leg length and low leg length on increasing leg power in volleyball extracurricular participants at SMA Negeri 1 Sedayu". The calculation result is presented in Table 6 as follows.

Table 6. ANOVA Test Results Differences in Players with High and Low Leg Length on Increasing Leg Power

\begin{tabular}{cccccc}
\hline Source & $\begin{array}{c}\text { Type III Sum of } \\
\text { Squares }\end{array}$ & df & $\begin{array}{c}\text { Mean } \\
\text { Square }\end{array}$ & F & Sig \\
\hline Leg_Length & 18.050 & 1 & 18.050 & 38.000 & 0.000 \\
\hline
\end{tabular}

From the results of the ANOVA test in Table 6 above, it can be seen that the significance value of $p$ is 0.000 and the $F$ value is 38.000 . Because the significance value of $p$ is $0.000<0.05$, it means that $\mathrm{H}_{0}$ is rejected. Based on this, it means that there is a significant difference in influence. Based on the results of the analysis, players who had a high leg length of 3.50 were higher (good) compared to players who had a low leg length of 1.60 with a posttest average difference of 1.90. This means that the research hypothesis which states that «There is a significant difference in the effect between players with high leg length and low leg length on increasing leg power in volleyball extracurricular participants at SMA Negeri 1 Sedayu» has been proven.

Interaction Between Barbell Squats and Resistance Band Squats and Leg Length (High and Low) on Increasing Leg Power

The third hypothesis states "There is a significant interaction between barbell squats and squat resistance bands and leg length (high and low) on increasing the leg power of volleyball extracurricular participants at SMA Negeri 1 Sedayu". The calculation results are presented in Table 7 as follows.

From the results of the ANOVA test in Table 7 above, it can be seen that the significance value of $p$ is 0.000 and the $\mathrm{F}$ value is 88.526 . Because the significance value of $\mathrm{p}$ is $0.000<0.05$, it means that $\mathrm{H}_{0}$ is rejected. Based on this, it 


\section{Estimated Marginal Means of Leg Power}

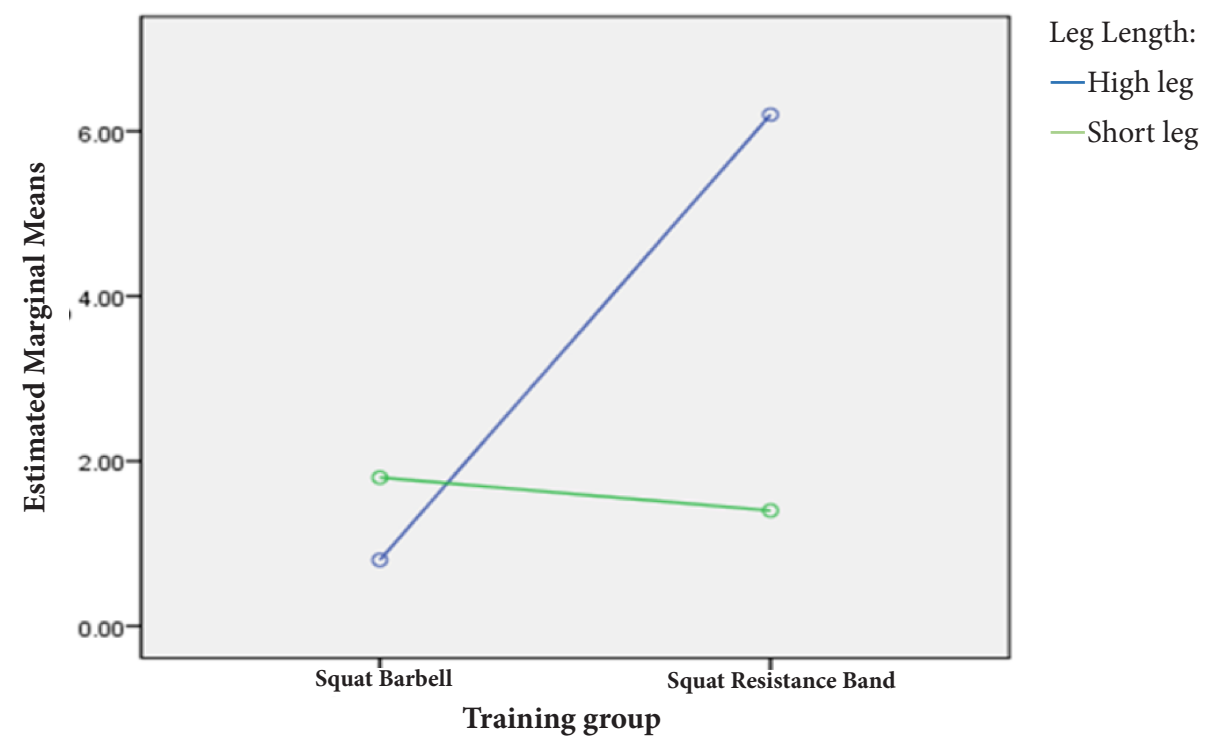

Fig. 2. Interaction Results between Barbell Squat Exercises and Squat Resistance Bands and Leg Length (High and Low) on Increasing Leg Power

Table 7. ANOVA Test Results Interaction between Barbell Squat Exercises and Squat Resistance Bands and Leg Length (High and Low) on Increasing Leg Power

\begin{tabular}{cccccc}
\hline Source & $\begin{array}{c}\text { Type III Sum of } \\
\text { Squares }\end{array}$ & df & $\begin{array}{c}\text { Mean } \\
\text { Square }\end{array}$ & F & Sig \\
\hline $\begin{array}{c}\text { Exercise_Group } \\
\text { Leg_Length }\end{array}$ & 42.050 & 1 & 42.050 & 88.526 & 0.000 \\
\hline
\end{tabular}

Table 8. Summary of Post Hoc Test Results

\begin{tabular}{ccccc}
\hline Group & Interaction & Mean Difference & Std. Error & Sig. \\
\hline \multirow{4}{*}{ A1B1 } & A2B1 & $-5.4000^{*}$ & .43589 & .000 \\
& A1B2 & -1.0000 & .43589 & .141 \\
& A2B2 & -.6000 & .43589 & .531 \\
\hline \multirow{4}{*}{ A2B1 } & A1B1 & $5.4000^{*}$ & .43589 & .000 \\
& A1B2 & $4.4000^{*}$ & .43589 & .000 \\
& A2B2 & $4.8000^{*}$ & .43589 & .000 \\
\hline \multirow{3}{*}{ A1B2 } & A1B1 & 1.0000 & .43589 & .141 \\
& A2B1 & $-4.4000^{*}$ & .43589 & .000 \\
& A2B2 & .4000 & .43589 & .796 \\
\hline \multirow{3}{*}{ A2B2 } & A1B1 & .6000 & .43589 & .531 \\
& A2B1 & $-4.8000^{*}$ & .43589 & .000 \\
& A1B2 & -.4000 & .43589 & .796 \\
\hline
\end{tabular}

means that the hypothesis which states "There is a significant interaction between barbell squats and squat resistance bands and leg length (high and low) on increasing the leg power of volleyball extracurricular participants at SMA Negeri 1 Sedayu" has been proven.

The graph of the interaction results between barbell squats and squat resistance bands and leg length (high and low) on increasing leg power of volleyball extracurricular participants at SMA Negeri 1 Sedayu can be seen in Figure 2 as follows.
After being tested there was an interaction between squat barbell and squat resistance band exercises and leg length (high and low) to increase the power of volleyball extracurricular participants at SMA Negeri 1 Sedayu, it is necessary to conduct further tests using Tukey test. Further test results can be found in Table 8 below:

Based on Table 8 tukey test calculation results on asterisk marks $\left(^{*}\right)$ show that pairs that have significantly different interactions or pairs are: (1) A1B1-A2B1, (2) A2B1$\mathrm{A} 1 \mathrm{~B} 2$, (3) A2B1-A2B2, while other pairs are stated to have no differences in influence are: (1) A1B1-A1B2, (2) A1B1$\mathrm{A} 2 \mathrm{~B} 2$, and (3) A2B2-A1B2.

\section{Discussion}

The Difference in the Effect of Barbell Squats and Resistance Band Squats on Increasing Leg Power

Based on the test, it is known that there is a significant difference in the effect of barbell squats and resistance band squats on increasing leg power of volleyball extracurricular participants at SMA Negeri 1 Sedayu. The squat resistance band exercise group was higher (good) compared to the barbell squat exercise group in increasing leg power. A study from Yoon et al. (2017) explain that the use of elastic bands provides a significant increase in the level of cognitive function, physical function, and muscle strength. Research from Chowdhary, Bhowmik, \& Mahapatra (2015) shows that exercise using elastic bands has increased muscle activation and become an effective method for building muscle hypertrophy in low-activity adults. With the described characteristics of elastic bands, this tool is suitable for use as an alternative to strength training for the general public, athletes, people with disabilities (Dhar \& Agarwal, 2015), the elderly (Nyberg et al. 2014), children (Şahin, Aslan, \& Demir, 2016) even people who are healing muscles (Skals et al., 2018) and have even recently been modified and applied 
to larger functions. The use of alternative tools can make the process of training athletes with special needs easier and certainly become safer and more friendly.

As stated by Shoepe et al. (2011) that "In recent years, one of these that has gained widespread acceptance in training programs throughout the world is the combination of elastic bands (EB) added to free weight (FW) exercises". Exercise using resistance bands is an alternative to weight training using rubber or elastic cables as resistance (Kim et al., 2015). Resistance bands have different lengths and levels of elasticity so the resistance weights are also different. Before using this resistance band should be ensured in advance the condition of elastic rubber so that it doesn not break at the time of use, because if it breaks, it will be able to endanger safety. In addition, it must also be ensured that the pivot point where the resistance bands are attached must be strong, so that exercises can be done comfortably and safely (Nasrulloh \& Wicaksono, 2020).

Resistance training is also known as strength training or weight training which is often used as an effective training method to develop muscle fitness (Ozsu, 2018). Based on the results of the study (Loturco, et al. 2014) concluded that the resistance training model to increase agility, speed and explosive power of the leg muscles uses exercises as smith press, seated press, squat, lying dumbbell leg cruel, leg extension, leg press, standing barbell curls, lying barble extensions and sit ups have an effect on increasing agility, speed and explosive power of the leg muscles. Meanwhile, research conducted by Biçer et al. (2015) concluded that resistance training models for speed enhancement using leg extension exercises, leg curls, leg press and seated calf raises have an effect on speed improvement.

The energy system for resistance training produces changes in anaerobic capacity, an increase in the phosphagen system (ATP-PC), and the lactic acid system (glycolysis), (Fox, in Sakti \& Irmansyah, 2016). Anaerobic is the amount of energy released by cellular metabolic processes without involving oxygen (Çakmakçı, Selçuk, \& Çakmakçı, 2017). Anaerobic is arguably a rapid muscle fiber energy system that does not require oxygen $(\mathrm{O} 2)$. The principles of weight training include frequency, intensity, duration, type, progressively increasing load, individual, specific, adaptation and recovery, (Nasrulloh, Prasetyo, \& Apriyanto, 2018). According to Chen, Zhang, and Meng (2018) resistance training is an exercise program that causes muscles to contract against external loads in the hope of increasing endurance, strength, muscle mass. Resistance exercises are an ideal partner for plyometric exercises as they help prepare the muscles for the rapid loading impact of plyometric exercises. In resistance exercises, athletes work to develop an eccentric phase of muscle contraction by first losing body or weight and then overcoming weight using concentric contractions.

Milić, Grgantov, \& Stipkov (2016), where a combination of resistance band exercises is very effectively used to increase the height of the jump and the strength of the legs, increase speed, agility. According to Coker (Oldenburg, 2015), that exercise can cause muscles to become responsive to loads, enlargement of muscle fibers, an increase in the number of capillaries, an increase in the number and size of mitochondria, and an increase in contractile proteins. The same opinion is said by Lamb (Oldenburg, 2015) stating that exercise can affect muscle hypertrophy, mitochondrial size, increase myofibril and sacoplasmic size, increase ATP-PC concentration and glycolysis enzymes. With the occurrence of muscle hypertrophy and improvement of the nervous system, as well as increased contractile protein, it will cause increased muscle strength. As stated by Bompa and Buzzichelli (2015) that muscle strength is affected by cross-sectional latitude or diameter of muscles especially myosin filament diameter, rapid muscle fiber recruitment ability and muscle synchronization in motion action.

The Difference in the Effect between Players who have High Leg Length and Low Leg Length on Increasing Leg Power

The results of the analysis showed that there was a significant difference in the effect of players with high leg length and low leg length on increasing leg power of volleyball extracurricular participants at SMA Negeri 1 Sedayu. Players who have high leg length are higher (good) compared to players who have low leg length to increase leg power. These results are strengthened in the research of Sardiman, Hidayah, and Soekardi (2017) that there is a difference in the effect between students who have leg length on increasing jump power abilities with a significant value of 0.00. Tanos et al., (2016) added that basically someone who has long legs will reach a longer jump distance compared to people who have short legs, because long legs can perform better leg swings when doing longer leg-range movements upon landing.

The results of research conducted on elite volleyball players showed that there was an effect of body weight, calf length, maximum ankle circumference, and leg length on vertical jumps (Martinez, 2017). People who have long legs can certainly make better jumps than people with short legs, meaning that they are in the same situation. As stated by Pasau (Ridwan, 2018) that people who have high physique and large average physical abilities such as strength, speed, heart-lung endurance, muscle endurance and others, more better than people who are small and short.

The Interaction between Barbell Squats and Resistance Band Squats and Leg Length (High and Low) on Increasing Leg Power

Based on the results that have been stated in the results of this study that there is a significant interaction between barbell squats and resistance band squats and leg length (high and low) on increasing leg power of volleyball extracurricular participants at SMA Negeri 1 Sedayu. The results showed that the squat resistance band exercise group was a more effective method for players with high leg length and the barbell squat exercise group was more effective for players with low leg length. The resulting interaction is that the group of athletes who have a height above average are more suitable if given resistance band exercises with tools, while the group of athletes who have a height below average is more suitable if given resistance band exercises without tools.

From the results of this form of interaction it appears that the main factors of the study in the form of two factors showed significant interactions. In the results of this study, the interaction means that in each cell or group there is a difference in the influence of each paired group. The pairs that have interactions or partners that are significantly different are as follows:

- The group of athletes who were trained using the squat resistance band exercise method with high leg length 
was better than the athlete trained using the barbell squat exercise method with high leg length, with $\mathrm{p}<0.05$.

- The group of athletes who were trained using the squat resistance band exercise method with high leg length was better than the group of athletes trained using the barbell squat exercise method with low leg length, with $\mathrm{p}<0.05$.

- The group of athletes who were trained using the squat resistance band exercise method with high leg lengths was better than the group of athletes trained using the squat resistance band training method with low leg length, with $\mathrm{p}<0.05$.

\section{Conclusions}

Based on the results of the research and the results of the data analysis that has been carried out, the following conclusions are obtained:

1. There is a significant difference in the effect of barbell squats and resistance band squats on increasing leg power of volleyball extracurricular participants at SMA Negeri 1 Sedayu. The squat resistance band exercise group was higher (good) compared to the barbell squat exercise group on increasing leg power.

2. There is a significant difference in the effect between players who have high leg length and low leg length on the increase in leg power of volleyball extracurricular participants at SMA Negeri 1 Sedayu. Players who have high leg length are higher (good) compared to players who have low leg length to increase leg power.

3. There is a significant interaction between barbell squats and squat resistance bands and leg length (high and low) on the increase in leg power of volleyball extracurricular participants at SMA Negeri 1 Sedayu. The pairs that have interactions or partners that are significantly different are as follows:

- The group of athletes who were trained using the squat resistance band exercise method with high leg length was better than the athlete trained using the barbell squat exercise method with high leg length, with $\mathrm{p}<0.05$.

- The group of athletes who were trained using the squat resistance band exercise method with high leg length was better than the group of athletes trained using the barbell squat exercise method with low leg length, with $\mathrm{p}<0.05$.

- The group of athletes who were trained using the squat resistance band exercise method with high leg lengths was better than the group of athletes trained using the squat resistance band training method with low leg length, with $\mathrm{p}<0.05$.

\section{Acknowledgement}

This research is supported by Yogyakarta State University and Institute of Advanced Science, Engineering, and Education (IASEE).

\section{Conflict of interest}

We know of no conflicts of interest associated with this publication, and there has been no significant financial support for this work that could have influenced its outcome. As corresponding author, I confirm that the manuscript has been read and approved for submission by all the named authors.

\section{References}

Sarabia, J. M., Moya-Ramón, M., Hernández-Davó, J. L., Fernandez-Fernandez, J., \& Sabido, R. (2017). The effects of training with loads that maximise power output and individualised repetitions vs. Traditional power training. PLOS ONE, 12(10), e0186601. https://doi.org/10.1371/journal.pone.0186601

Kumar, S., Goswami, J., \& Kumar, A. (2016). Effect of training program on volleyball skills of inter-university level volleyball players. International Journal of Movement Education and Sports Sciences (IJMESS), IV(1).

Zemková, E., Vilman, T., Cepková, A., Uvaček, M., Olej, P., \& Šimonek, J. (2017). Enhancement of power in the concentric phase of the squat and jump: Between-athlete differences and sport-specific patterns. Journal of Human Sport and Exercise, 12(1).

https://doi.org/10.14198/jhse.2017.121.03

Bompa, T.O., \& Haff, G. (2019). Periodization theory and methodology of training. USA: Sheridan Books.

Suresh, A. \& Perinbaraj, B. (2016). Effect of saq training associated with speed training on agility explosive power and speed among engineering college sports persons. International Journal of Recent Research and Applied Studies, 3(6).

Wirth, K., Keiner, M., Hartmann, H., Sander, A., \& Mickel, C. (2016). Effect of 8 weeks of free-weight and machinebased strength training on strength and power performance. Journal of Human Kinetics, 53(1), 201-210. https://doi.org/10.1515/hukin-2016-0023

Challoumas, D., \& Artemiou, A. (2018). Predictors of Attack Performance in High-Level Male Volleyball Players. International Journal of Sports Physiology and Performance, 13(9), 1230-1236. https://doi.org/10.1123/ijspp.2018-0125

Aghajani, R., Hojjati, Z., \& Elmiyeh, A. (2014). The Effects of Plyometric and Resistance Training on Explosive Power and Strength of Young Male Volleyball Players. Annals of Applied Sport Science, 2(1), 45-52. https://doi.org/10.18869/acadpub.aassjournal.2.1.45

Bryanton, M. A., Kennedy, M. D., Carey, J. P., \& Chiu, L. Z. F. (2012). Effect of Squat Depth and Barbell Load on Relative Muscular Effort in Squatting. Journal of Strength and Conditioning Research, 26(10), 2820-2828. https://doi.org/10.1519/JSC.0b013e31826791a7

Csapo, R., \& Alegre, L. M. (2016). Effects of resistance training with moderate vs heavy loads on muscle mass and strength in the elderly: A meta-analysis: Strength training: high vs lighter loads. Scandinavian Journal of Medicine \& Science in Sports, 26(9), 995-1006. https://doi.org/10.1111/sms.12536

Wallace, B. J., Winchester, J. B., \& McGuigan, M. R. (2006). Effects of Elastic Bands on Force and Power Characteristics During the Back Squat Exercise. The Journal of Strength and Conditioning Research, 20(2), 268. https://doi.org/10.1519/R-16854.1 
Radu, L.-E., Făgăraș, S.-P., \& Graur, C. (2015). Lower Limb Power in Young Volleyball Players. Procedia - Social and Behavioral Sciences, 191, 1501-1505. https://doi.org/10.1016/j.sbspro.2015.04.371

Sugiyono. (2015). Metode penelitian pendidikan: pendekatan kuantitatif, kualitatif, dan R \& D. Bandung: Alfabeta.

Siyoto, S \& Sodik, A. (2015). Dasar metodologi penelitian. Yogyakarta: Literasi Media Publishing.

Dearing, J. (2019). Volleyball fundamentals, second edition. Illinois : Human Kinetics.

Yoon, D. H., Kang, D., Kim, H., Kim, J.-S., Song, H. S., \& Song, W. (2017). Effect of elastic band-based high-speed power training on cognitive function, physical performance and muscle strength in older women with mild cognitive impairment: Effects of elastic band HSPT in Aging. Geriatrics \& Gerontology International, 17(5), 765-772. https://doi.org/10.1111/ggi.12784

Chowdhary, B, Bhowmik, A, \& Mahapatra, N. (2015). Comparison of explosive strength between football and volley ball players of jamboni block. Journal of Sports and Physical Education, 2(2), 12-13.

Dhar, S., \& Agarwal, S. (2015). Effectiveness of an Elastic Band Exercise Protocol in Tri-Compartmental Osteoarthritis of the Knee. Indian Journal of Physiotherapy and Occupational Therapy - An International Journal, 9(2), 176. https://doi.org/10.5958/0973-5674.2015.00076.3

Nyberg, A., Hedlund, M., Kolberg, A., Alm, L., Lindström, B., \& Wadell, K. (2014). The accuracy of using elastic resistance bands to evaluate muscular strength. European Journal of Physiotherapy, 16(2), 104-112. https://doi.org/10.3109/21679169.2014.889746

Şahin, G., Aslan, M., \& Demir, E. (2016). Short-term effect of back squat with an elastic band on the squat and vertical jump performance in trained children. Journal of Physical Education and Sport, 16(1), 97.

Skals, S., Vinstrup, J., Sundstrup, E., Jakobsen, M. D., Andersen, C. H., \& Andersen, L. L. (2018). Shoulder and arm muscle activity during elastic band exercises performed in a hospital bed. The Physician and Sportsmedicine, 46(2), 233-241.

https://doi.org/10.1080/00913847.2018.1441580

Shoepe, T., Ramirez, D., Rovetti, R., Kohler, D., \& Almstedt, H. (2011). The Effects of 24 weeks of Resistance Training with Simultaneous Elastic and Free Weight Loading on Muscular Performance of Novice Lifters. Journal of Human Kinetics, 29(2011), 93-106. https://doi.org/10.2478/v10078-011-0043-8

Kim, S.-H., Kwon, O.-Y., Park, K.-N., Jeon, I.-C., \& Weon, J.-H. (2015). Lower Extremity Strength and the Range of Motion in Relation to Squat Depth. Journal of Human Kinetics, 45(1), 59-69. https://doi.org/10.1515/hukin-2015-0007

Nasrulloh, A., \& Wicaksono, I. S. (2020). Latihan bodyweight dengan total-body resistance exercise (TRX) dapat meningkatkan kekuatan otot. Jurnal Keolahragaan, 8(1), 52-62. https://doi.org/10.21831/jk.v8i1.31208

Özsu, İ. (2018). Effects of 6-Week Resistance Elastic Band Exercise on Functional Performances of 8-9 Year-Old Children. Journal of Education and Training Studies, 6(12a), 23. https://doi.org/10.11114/jets.v6i12a.3887

Loturco, I., Nakamura, F. Y., Tricoli, V., Kobal, R., Cal Abad, C. C., Kitamura, K., Ugrinowitsch, C., Gil, S., Pereira, L. A., \& González-Badillo, J. J. (2015). Determining the Optimum Power Load in Jump Squat Using the Mean Propulsive Velocity. PLOS ONE, 10(10), e0140102. https://doi.org/10.1371/journal.pone.0140102

Biçher, Özdal, M, Akcan, F, Mendeş, F, \& Patlar, S. (2015). Effect of strength training program with elastic band on strength parameter. Journal Biology Exercise, 11(2).

Sakti, N.W.P \& Irmansyah, J. (2016). Pengaruh latihan pyometric dan resistance terhadap peningkatan kecepatan dan daya ledak otot tungkai. Jurnal Ilmiah Mandala Education, 2(2), 218-229. http://dx.doi.org/10.36312/jime.v2i2.111

Çakmakçı, O, Selçuk, M.S, Çakmakçı, E. (2017). The effect of resistance band training on the maximum force and anaerobic power of boxers. European Journal of Physical Education and Sport Science, 3(8).

Nasrulloh, A., Prasetyo, Y., \& Apriyanto, K.D. (2018). Dasardasar latihan beban. Yogyakarta: UNY Pres.

Chen, L., Zhang, H., \& Meng, L. (2018). Study on the influence of plyometric training on the explosive power of basketball players. International Journal of Physical Education, Sports and Health, 5(3), 140-143.

Milić, M., Grgantov, Z., \& Stipkov, M. (2016). Metric characteristics of the modified step-hop test for assessing specific agility in young female volleyball players. Sport Science, 9(2), 104.

Oldenburg, S. (2015). Complete conditioning for volleyball. USA: Human Kinetics.

Bompa, T.O. \& Buzzichelli, C. (2015). Periodization training for sport. United States: Human Kinetics.

Sardiman, Hidayah, \& Soekardi (2017). Pengaruh latihan plyometric dan panjang tungkai terhadap peningkatan power lompatan dan smash kedeng sepak takraw. Journal of Physical Education and Sports, 6(3), 286-290.

Tanos, C.M., Moningka, M., \& Rumampuk, J. (2016). Hubungan panjang tungkai dengan kemampuan lompat jauh gaya jongkok siswa kelas X SMA Negeri 9 Binsus Manado. Jurnal Kedokteran Klinik (JKK), 1(1).

Martinez, D. B. (2017). Consideration for power and capacity in volleyball vertical jump performance. Strength \& Conditioning Journal, 39(4), 36-48.

Ridwan, A. (2018). Hubungan panjang tungkai dan daya ledak tungkai dengan kemampuan lompat jauh murid SD Negeri 5 Sinjai Utara. SPORTIVE: Journal of Physical Education, Sport and Recreation, 1(2), 59. https://doi.org/10.26858/sportive.v1i2.6376 


\title{
ВПЛИВ ТРЕНУВАННЯ ТА ДОВЖИНИ НІГ НА ЗБІЛЬШЕННЯ СИЛИ НІГ УЧАСНИКІВ ПОЗАШКІЛЬНИХ ЗАНЯТЬ 3 ВОЛЕЙБОЛУ
}

\author{
Ахмад Насруллох ${ }^{1 \mathrm{BBCDE}}$, Путрі Девіана ${ }^{1 \mathrm{BDE}}$, Ріна Юніана $^{1 \mathrm{BCE}}$, Кукух Вахьюдін Пратама ${ }^{2 \mathrm{CDE}}$ \\ 'Державний університет Джок'якарти \\ ${ }^{2}$ Інститут передової науки, техніки та освіти
}

Авторський вклад: А - дизайн дослідження; В - збір даних; C - статаналіз; D - підготовка рукопису; Е - збір коштів

Реферат. Стаття: 9 с., 8 табл., 2 рис., 38 джерел.

Мета дослідження. Це дослідження має на меті визначити: (1) різницю у впливі присідань зі штангою і вправ 3 обтяженнями на збільшення сили ніг; (2) різницю у впливі на збільшення сили ніг у гравців з більшою і меншою довжиною ніг; (3) взаємодію присідань зі штангою і присідань $з$ опором зі стрічкою в залежності від довжини ніг для збільшення сили ніг учасників волейбольної позаурочної програми.

Матеріали та методи. Це експериментальне дослідження з використанням факторної схеми $2 \times 2$. У дослідженні взяли участь 38 волейболістів, які брали участь в позакласній програмі SMA Negeri 1 Sedayu. Вибірка в цьому дослідженні становила 20 осіб. Вимірювання довжини ніг здійснювалося за допомогою рулетки. Сила ніг вимірювалася за допомогою вертикального стрибка. Для обробки даних використовувався метод двохфакторного дисперсійного аналізу.

Результати. Результати показали, що (1) між присіданнями зі штангою і вправами з опором зі стрічкою спостерігається значна різниця у впливі на збільшення сили ніг, значення $\mathrm{F}=65,789$ та значення достовірності $\mathrm{p}=0,000$ $(<0,05)$. Група присідань 3 опором зі стрічкою має більш високий діапазон опору (добре) в порівнянні з групою присідань зі штангою з середньою різницею 2,5. (2) Спостерігалася значна різниця у впливі у гравців з різною довжиною ніг на збільшення сили ніг учасників позакласних занять 3 волейболу, доведено, що значення $\mathrm{F}$ становить 38,000, а значення достовірності $\mathrm{p}=0,000(<0,05)$. Гравці з більшою довжиною ніг в порівнянні з гравцями з меншою довжиною ніг мають вище (добре) результат із середньою різницею 1,90. (3) Спостерігалася значна взаємодія між присіданням зі штангою і присіданням з опором зі стрічкою і довжиною ніг на збільшення сили ніг, значення $\mathrm{F}=88,256$, $\mathrm{p}=0,000(<0,05)$.

Висновки. Спостерігалася значна різниця у впливі присідань зі штангою і присідань з опором зі стрічкою на збільшення сили ніг, була значна різниця у впливі між гравцями з більшою довжиною ніг і меншою довжиною ніг на збільшення сили ніг. Спостерігалася значуща взаємодія між присіданнями зі штангою і присіданнями 3 опором зі стрічкою і довжиною ніг на збільшення сили ніг учасників позаурочної програми з волейболу.

Ключові слова: присідання зі штангою, присідання 3 еспандером, сила ніг, довжина ніг.

\section{Information about the authors:}

Nasrulloh, A.: ahmadnasrulloh@uny.ac.id; https://orcid.org/0000-0003-2859-7091; Department of Sports Science, Faculty of Sport Science, Yogyakarta State University, Jl. Colombo Yogyakarta No.1, Karang Malang, Caturtunggal, Kec. Depok, Kabupaten Sleman, Daerah Istimewa Yogyakarta 55281, Indonesia.

Deviana, P.: putrideviani.2018@student.uny.ac.id; https://orcid.org/0000-0002-0174-8585; Department of Sports Science, Faculty of Sport Science, Yogyakarta State University, Jl. Colombo Yogyakarta No.1, Karang Malang, Caturtunggal, Kec. Depok, Kabupaten Sleman, Daerah Istimewa Yogyakarta 55281, Indonesia.

Yuniana, R.: rinayuniana@uny.ac.id; https://orcid.org/0000-0001-6278-1015; Department of Sports Science, Faculty of Sport Science, Yogyakarta State University, Jl. Colombo Yogyakarta No.1, Karang Malang, Caturtunggal, Kec. Depok, Kabupaten Sleman, Daerah Istimewa Yogyakarta 55281, Indonesia.

Pratama, K.W.: kukuh.pratama@iasee.org; https://orcid.org/0000-0003-4518-6358; Research and Development Institute of Advanced Science, Engineering, and Education (IASEE), A-03A-05, Suria Jelutong, Jalan Bazar U8/99, Shah Alam 40150, Selangor, Malaysia.

Cite this article as: Nasrulloh, A., Deviana, P., Yuniana, R., \& Pratama, K.W. (2021). The Effect of Squat Training and Leg Length in Increasing the Leg Power of Volleyball Extracurricular Participants. Teoriâ ta Metodika Fizičnogo Vihovannâ, 21(3), $244-252$. https://doi.org/10.17309/tmfv.2021.3.08

Received: 06.08.2021. Accepted: 20.08.2021. Published: 25.09.2021

This work is licensed under a Creative Commons Attribution 4.0 International License (http://creativecommons.org/licenses/by/4.0). 